\title{
CLS to Higher Education Administrator: The Price They Paid
}

\author{
SUZANNE CAMPBELL, BARBARA Y. LACOST
}

OBJECTIVES: To identify the barriers and/or obstacles these women experienced during their career paths as women clinical laboratory scientists who transitioned to higher education administration.

To identify how being a woman influenced their careers as higher education administrators.

METHODS: A multi-site case study design was selected for this qualitative research involving a purposive sample of eight research participants. Data collection was guided by ten open-ended questions in seven face-to-face and one telephone semi-formal interviews.

SETTINGS AND PARTICIPANTS: The purposive sample included women clinical laboratory scientists who held a current higher education administrative position at the dean's level, including associate and assistant dean positions, in a university setting. The participants were located in eight higher education institutions in Nebraska, Illinois, Ohio, Tennessee, Missouri, and Texas.

MAIN OUTCOMES MEASURES: The price women pay, gender considerations, a need for balance, existence/absence of the glass ceiling for women in higher education administration.

RESULTS: Making personal sacrifices, struggling with gender stereotypes, being a woman, knowing you are okay, and possessing the ability to separate the personal from the professional were identified by this group of women as challenging experiences as they obtained and maintained a position as a higher education administrator. Additionally, they described the need for balance, a support system, and how they successfully managed their marriage, family, and career. The participants presented conflicting statements concerning the existence of the glass ceiling for women in higher education administration.

CONCLUSION: The participants in this study obtained positions in higher education administration but they indicated they have paid a price. Each of the participants indicated their obstacles included making a personal sacrifice, being treated differently because they were women, and needing to find a balance in their responsibilities related to their careers, marriages, and families. The majority of the participants believe there is a slight increase in the number of opportunities for women in higher education administration.

INDEX TERMS: career paths of women clinical laboratory scientists; women higher education administrators; barriers/obstacles for women higher education administrators.

Clin Lab Sci 2010;23(3):157

Suzanne Campbell, PhD, MT(ASCP), Medical Laboratory Technician Program, Seward County Community College/Area Technical School, Liberal, Kansas.

Barbara Y. LaCost, PhD, College of Education and Human Sciences, University of Nebraska-Lincoln, Lincoln, Nebraska.

Address for correspondence: Suzanne Campbell, PhD, MT(ASCP), Program Coordinator and Faculty, Medical Laboratory Technician Program, Seward County Community College/Area Technical School, 520 N. Washington, Liberal, KS 67901. (620) 417-1403, (620) 417-1449 (fax).suzanne.campbell@sccc.edu.

\section{INTRODUCTION}

The purpose for conducting this qualitative study was to investigate and document the career paths of women 


\section{RESEARCH AND REPORTS}

clinical laboratory scientists who have transitioned from the clinical setting to the higher education arena and held administrative positions at the dean's level, including assistant and associate dean positions. This research sought to identify: 1) the barriers and/or obstacles these women experienced during their career paths as women clinical laboratory scientists who transitioned to higher education administration and 2) how being a woman influenced their careers as higher education administrators.

Three major themes emerged from the data. They included: Getting to the Right Place at the Right Time, The Right Navigational Skills are Required, and The Right Place Comes with a Price. The Right Time Right Place theme described the three different career stops experienced by each of the participants. These findings were published in the Summer 2009 edition of Clinical Laboratory Science. ${ }^{1}$ The Right Navigational Skills theme was developed from two categories: don't wait for opportunity to knock and communication is the key. These findings were published in the Winter 2010 edition of Clinical Laboratory Science. ${ }^{2}$ The Right Place Comes with a Price theme findings are presented here. Figure 1 outlines the relationship between the major themes and categories developed from the research data.

\section{RESEARCH QUESTIONS}

To investigate the career paths of women clinical laboratory scientists who held higher education administrative positions, the following questions were considered.

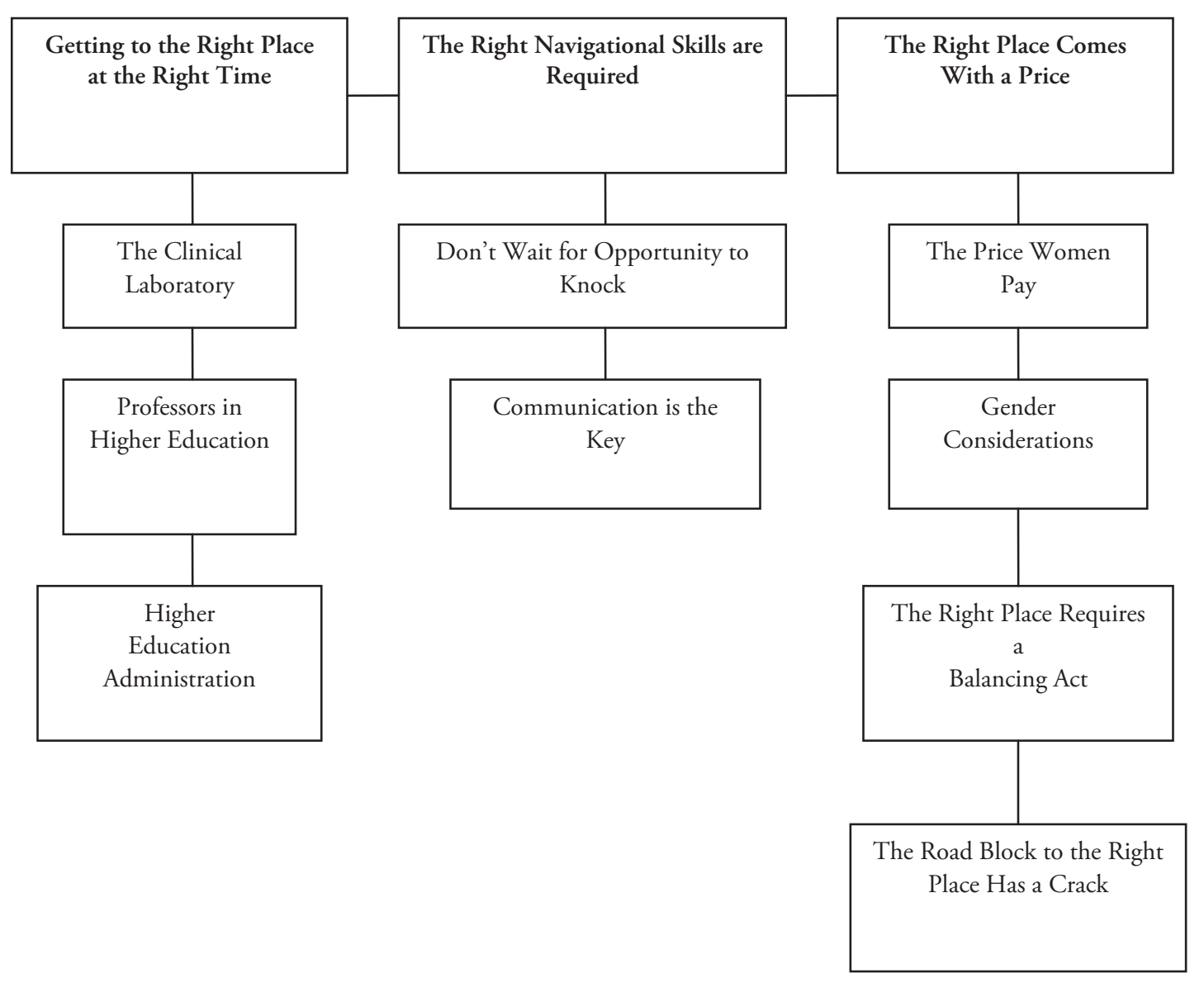

Figure 1: CLS to Higher Education Administrator Research Themes and Categories 


\section{RESEARCH AND REPORTS}

1. What are the lived experiences of women higher education administrators with a background in clinical laboratory science during their career paths?

2. What skills, training, and/or professional development opportunities enabled these women to become successful higher education administrators when their initial academic area of study was clinical laboratory science?

3. What barriers and/or obstacles have these women experienced during their career paths as women clinical laboratory scientists who transitioned to higher education administration?

4. How has being a woman influenced their careers as higher education administrators?

This report focuses on the findings related to the research questions that addressed the barriers and/or obstacles these women may have experienced as higher education administrators and how being a woman has influenced their careers.

\section{LITERATURE REVIEW}

The literature reviewed to support the categories of this theme included an assessment of the number of women in higher education administration positions, genderrelated considerations, and the glass ceiling theory.

\section{Women in Higher Education Administration Positions}

In 1920 , women constituted $47 \%$ of the undergraduate enrollment in higher education. Thirty-two percent of college presidents, professors, and instructors were women in 1930. During the period from 1930 to 1960, the proportion of women receiving bachelor degrees and their first professional degrees fell to $24 \%$. During this same time, only $9 \%$ of doctoral degree recipients were women. In 1965, the Higher Education Act helped to increase the number of women undergraduates. Legislative actions such as Affirmative Action and Title IX also opened the doors of opportunity for women in higher education. During the 1970s, women faculty and administrators strived to find ways to improve their status within their professions. ${ }^{3}$
In 1978, women made up $52 \%$ of students at the masters level and $40 \%$ of students at the doctorate level. ${ }^{4}$ Women constituted $52 \%$ of the total student enrollment in higher education in 1980. During this same period, women made up $25 \%$ of full-time faculty in higher education: $8 \%$ were full professors, $16 \%$ were associate professors, $28 \%$ were assistant professors, $29 \%$ were instructors, and $18 \%$ held deanships. ${ }^{3}$

During the mid 1990's, the number of women that were employed as new faculty was 39\%. This number of women was almost five times greater than the number of veteran women faculty. It was also noted that research institutions hired women at twice the rate of comprehensive institutions. ${ }^{5}$

At the close of the $20^{\text {th }}$ century, "Women [held] 27\% of all deanships" however, "only $8 \%$ of all law school deanships and 3\% of medical school deanships [were] held by women." Additionally, "women are 15\% of chief academic officers... but $70 \%$ of these positions held by women are in colleges with fewer than 1,000 students. Women chief academic officers are rarely found in research and doctoral universities." Furthermore,

Women comprise $19 \%$ of all presidents of colleges and universities... yet $70 \%$ of these women presidents head schools with 3,000 or fewer students, religious or women's colleges, or two year institutions. Only $2 \%$ of all women presidents head major research universities. ${ }^{6}$

\section{Gender-related Considerations}

Women were not readily accepted into the "old boy's network" such as an administrative council. Women have been treated differently because of gender and have often worked in a non-supportive higher education system. Typical male roles were defined by traits such as dominance, achievement, autonomy, and aggression. ${ }^{7}$ The male role characteristics were accepted in leadership positions. The female role was defined by emotionalism, passivity, timidity, deference, and self-abasement. The female role characteristics were not seen as those of people in leadership positions. Women were perceived as less competent than men. This perceived incompetence was a barrier to women obtaining 


\section{RESEARCH AND REPORTS}

educational leadership positions. ${ }^{7,8}$ To achieve positions as educational leaders, women have been required to perform at a higher skill level than males. ${ }^{9}$ Women must demonstrate to existing leadership that they are capable of leadership roles.

Men dominate education in the number of administrative positions held and the amount of money earned. Men also dominate the decision-making processes that may discourage women from entering administrative ranks. ${ }^{6,7}$ Women must hold a higher level of certification, i.e., advanced degrees, than men to obtain the same position. ${ }^{10}$ Women must be aware that administration will promote those who demonstrate leadership characteristics. Presidents and other leaders must recognize and promote a climate providing opportunities for qualified women. It is vital that university leaders support women in leadership roles.

Women have also battled an uneven playing field with regard to salary compensation level of formal training, expectations of knowledge or skill level, and underrepresentation at all levels of higher education. ${ }^{8}$ The New Agenda discussed by Shavlik and Touchton (1992) called for correction of inequities in hiring, advancement, and salary of female faculty, administrators, and staff. ${ }^{11}$ For most women, earning a doctoral degree is seen as a benefit when their goal is to obtain an educational leadership position. ${ }^{12,13}$ To increase the number of women in educational leadership positions, women must obtain the necessary credentials in educational administration, apply for educational administration positions, and encourage other women to strive for positions in educational leadership. ${ }^{7,14}$

Higher education institutions play a major role in bringing women into the educational leadership ranks. Institutions need to improve female representation in leadership positions. The availability of administrative internships provides development of formal and informal networks, allows women the opportunity to participate in administrative processes and budget preparation, and provides opportunity to observe the decision-making process. Institutions should identify women within their system that have potential leadership skills and a desire to hold leadership positions, provide opportunities to develop those leadership skills, and select from this group to fill administrative positions. ${ }^{6,8}$ The campus climate should also provide an institutional atmosphere and environment to foster women's personal, academic, and professional development. ${ }^{3,15}$

\section{The Glass Ceiling Theory}

A 1991 report by the United States Department of Labor defines the glass ceiling as "those artificial barriers based on attitudinal or organizational bias that prevent qualified individuals from advancing upward in their organization into management-level positions." 16 The study further stated, "attitudinal and organizational barriers...are an indication that the progress of minorities and women in corporate America is affected by more than qualifications and career choices." 16 The attitudinal and organizational barriers were identified as ineffective recruitment practices, a lack of development practices and credential building experiences, and the lack of senior-level executive accountability of Equal Employment Opportunity (EEO) responsibilities.

Additional follow up studies were conducted to determine the status of the glass ceiling. The 1997 United States Department of Labor report cited barriers similar to the previous reports. The barriers "include lack of good faith efforts in the following areas: management development programs and mentoring, EEO accountability, and outreach and recruitment. ${ }^{17}$ The conclusion of the report demonstrated the continual existence of the glass ceiling for women and minorities.

The existence of the glass ceiling for women in higher education administration is still a topic of debate. When considering the data previously presented, it is possible to conclude "the glass ceiling is still firmly intact in academe at the start of the $21^{\text {st }}$ century." Women experience severe declines in participation rates at each step of the educational system; from their first degree to the doctoral level and then entrance and ascension among faculty ranks. ${ }^{10}$ In higher education worldwide, the higher the level of administration - the fewer the number of women. ${ }^{10}$ 


\section{RESEARCH AND REPORTS}

However, the data also provide hope to those women seeking positions as a higher education administrator. Although the number of women at this level is less than optimal, they are making progress. With continued changes in governing board and administrator attitudes and increased opportunities for women that demonstrate the necessary skills and knowledge, women will continue to gain employment as higher education administrators, thus seeing a crack in the glass ceiling.

\section{METHODOLOGY}

\section{Case Study Design}

This case study of women higher education administrators with a background in clinical laboratory science sought to illustrate topics using a descriptive mode of the common themes developed from the data. ${ }^{18}$ The semi-formal interviews were audio recorded for transcription and subsequent data collection, and analysis.

After developing the initial categories, the researchers performed axial coding in which the data were assembled and reassembled. ${ }^{19}$ The axial coding portion of the data analysis included looking for descriptive wording for the topics, turning them into categories, and determining relationships between the topics. The last phase of coding involved the writing of the story line. ${ }^{19}$ To provide credibility to the data, member checks, rich-thick descriptions, and an external audit were employed. ${ }^{20}$

\section{Participant Demographics}

All participants had a previous history of experience in the clinical laboratory. The position titles of this group of women included dean, assistant dean, and associate dean.

The majority of the participants were between 50 and 59 years of age. Five of the eight clinical laboratory scientists were married at the time of the study; seven had children. All of the participants had earned advanced degrees: two possessed masters degrees, three earned doctorates of philosophy, one was all but dissertation (ABD), one held a doctorate of arts, and one held an educational doctorate. One woman was an assistant professor, two were associate professors, and five women were full professors. All had a minimum of ten years experience as a faculty member.

Each of the participants was assigned a pseudonym and a university name that corresponded with a Greek letter. The pseudonyms included Ann at Alpha University, Brianna at Beta University, Debra at Delta University, Gwen at Gamma University, Kelly at Kappa University, Lynn at Lambda University, Olive at Omega University, and Teresa at Theta University.

\section{RESULTS}

The theme presented here indicates that women can and do achieve positions in higher education administration, but they pay a price for that achievement. The Right Place Comes with a Price theme was based on four categories: The Price Women Pay, Gender Considerations, The Right Place Requires a Balancing Act, and The Road Block to the Right Place Has a Crack. These categories were supported by eleven codes and each was explored.

\section{The Price Women Pay}

\section{Personal Sacrifice}

The first category was supported by one code - personal sacrifice. Almost all of the participants commented they had made personal sacrifices in earning the position they held as a higher education administrator. Some of the participants truly believed the sacrifices made were a result of being a woman.

Seven of the participants in this study believed that they had paid that price. Ann stressed, "You always pay a price for choosing a professional career. It demands more of your time." Ann had less time available for social events. However, she made a conscientious effort not to give up time with her children when they were growing up. "I think I have paid more attention to the family. I don't think I have neglected the family but probably neglected the grandchildren." Furthermore, Ann said, "I think that women, in order to succeed, have to work harder. You have to be better than the rest of the group that were applying for the position. Noticeably better."

At one point in her career, Brianna had received major grant funding, had a new baby, and was being asked to 


\section{RESEARCH AND REPORTS}

move into administration. She stated, "Trying to do all of those things was a bit of a challenge. It was a wild couple of years." When presented with these opportunities almost simultaneously, Brianna said, "It was almost to the point that I had beaten myself up so badly getting funding, getting tenure that I needed to step back and enjoy the other part I had tried so hard to get - my son." Although a difficult decision, she decided to move to administration and not continue the grantfunded research.

\section{Gender Considerations}

This category includes several supporting areas that relate to gender issues. The gender related issues include: gender roles/stereotypes, being a woman, knowing you are okay, and separating personal from professional.

\section{Gender roles/stereotypes}

Debra was not readily accepted as the chairperson for the automotive technology program. She stated, "They [faculty] were very concerned that a female was coming as a division head and one who did not teach in their area." This was seen as a position that should be assumed by a male. Debra was able to eliminate those concerns by demonstrating her ability "to work with people to get them to work together. Being able to go from $A$ to $\mathrm{Z}$ on a project."

Teresa's experience with gender stereotypes occurred during her time in the science department as a faculty member. She commented, "I was exposed to a number of things that [were] probably sexual harassment. I was the only female in the department [and] was very skeptical at first when I moved. The previous two females in that department had not succeeded. There were some real problems and the men thought the last thing they needed was another female in the department. I worked with the men and [did] not make a big deal of it. [I] just interacted with them and served as their token female on many of the committees."

\section{Being a woman}

The majority of the participants shared experiences unique to them because they are female. Ann's experience took place when she was in college. During her physical chemistry class, the professor announced to the class "women didn't take classes like this" and "what was she doing - to think that she could take this class?" At point one in her biochemistry class, the professor called her up and said, "I don't know what I am going to do about this because you are getting a higher grade on this test, a higher grade in the course than your husband." Ann's reply was to give the earned grades for both. The professor replied, "I can't do that." Ann received an A and so did her husband.

To demonstrate her abilities as a woman, Teresa commented, "I built a trust to show that I could do the job and I could do it well." She further added, "I think women have to sometimes work twice as hard to prove that point - where [with] a man, it's just assumed. It took me a long time to really [see that]."

\section{Knowing you are okay}

Kelly suggested "keep who you are in mind and work within that. People will start to respect that." She strongly urged women to "be yourself and to be consistent with who you are." To know who you are and that you are okay may require some place or someone to bounce things off."

\section{Separating personal from professional}

One coping strategy that was identified by the participants was the ability to separate the personal from the professional. Brianna found herself in a position that required her to close the department where she had close personal ties. The members of this department were her friends and it was very difficult. She stated, "That's the hard part of being in administration. You have to separate how you feel about people personally from the kind of vision [that is] ... the bigger picture of the college." She shared the internal struggle with making that type of decision. The department faculty,

don't see how you agonize about the decisions and how you understand that you have people's careers and jobs in your hands. They don't see that. Sometimes people think it's a frivolous decision or that she likes one department over another.

Brianna said, "I don't think there's an appreciation and that takes a toll. There's no appreciation for the fact 


\section{RESEARCH AND REPORTS}

that you have to go through this personal agony. That's hard, that's really hard."

\section{The Right Place Requires a Balancing Act}

This category outlines the balancing act these participants were able to carry out that enabled them to obtain and maintain their positions as higher education administrators. These women recognized the need for balancing their career goals with marital and family commitments, and the importance of a support system.

\section{A need for balance}

Six of the participants discussed the need for balance in their lives. They were higher education administrators, mothers, and wives. To be successful in each area, a careful balance of time and effort was necessary. Brianna shared the struggle of "leav[ing] it at work," dealing with the demands on your time, and trying to carve out time for the family. For her, this is an added stressor. She said,

I leave work and [employees] call me all the way home in the car. I get home, have dinner, do homework [with my son], and have some hour of quality time - there is no time left for me. That's the biggest stressor in my life.

She commented, "I was up until two o'clock last night because I decided I had to read a book, or make a Christmas list, and I had to have two hours where nobody was asking me to do something."

At a juncture in her career as a CLS program director, Olive made a move that eliminated commuting that had previously taken time away from her daughter. She commented,

It was one of the most difficult decisions I've ever made. I enjoyed [the university] immensely and I was tenured. [I was] quite happy with the environment. I really had to do some soul searching because I was going to take a big cut in salary. My daughter was in high school at the time and I was commuting. The hours I was putting in were long. After some soul searching, [I] decided that Omega University is where I belonged.
Support systems

The majority of the participants in this study indicated the need for some type of support system. Brianna gave her husband the credit for her ability to balance being a wife, mother, and a professional woman. She commented, "My husband has always been very supportive. In fact, before we were married, I moved to do my post doc and he followed me. We've always been a partnership." Brianna shared, "I had opportunities for faculty appointments around the country and we decided to come back as a joint decision." Brianna and her husband had flexible schedules that allowed both of them to balance their career and family duties.

Teresa also had a very supportive husband. She stated, "He thought I was good and needed to have a career so he was very supportive in that and in moving forward." At the point in her career when Teresa was considering a chair position, her husband said, "I think you have to take opportunity when it knocks, and you should look at some of these things." She was called for an interview and offered the position.

\section{Maintaining balance}

Seven of the participants shared their experiences of "keeping three balls in the air at all times." This was the phrase that Lynn used to describe her attempt at balancing her career goals with her marital and family commitments. She further stated, "Those three balls are in the air almost all of the time for a woman. And knowing how to keep them all balanced [is difficult]." Lynn indicated,

I will leave at noon, no matter what, because Christmas parties will happen at my children's elementary school, and I will be gone. I do not feel guilty, because all day Saturday, I will be in commencement. I feel no guilt about that at all because it's just balancing the same thing. I do it guilt free.

Brianna was offered a position as the vice provost for programs and planning. This was a fairly prestigious position on campus. She was promised flexibility in terms of hours and family commitments but she just did not believe it. In her current position, she was involved in "a lot of very interesting projects and a 


\section{RESEARCH AND REPORTS}

number of things that [she] was really vested in." She was really interested in the new position but yet was unsure about "doing what I see as the more interesting part of the job." The decision to turn down the position came when she "was just sitting on the porch on day with my son in my lap and I said, 'Why am I even considering taking on more responsibility now?' He is too young." She was the top candidate for the position. When she pulled out, administration tried for weeks to convince her to reconsider. Her decision to remain in her position was her strategy for balancing her career needs with her family needs.

\section{The Road Block to the Right Place Has a Crack}

Although the participants of this research project had conflicting messages with regard to the glass ceiling in higher education administration, the majority did indicate some progress had been made. However, they were quick to point out that women still encounter inequity when compared to their male colleagues.

\section{The glass ceiling is now Teflon}

It has been said that the glass ceiling is breaking for women in the business world and women are now obtaining executive positions. When asked if this was also occurring in higher education, Debra replied, "I disagree. I don't think it is happening in business either. I think the glass ceiling has turned into a Teflon ceiling and Teflon is much harder to break than glass." Debra believed that the studies tended to look at the numbers and did not consider the salaries and other related issues.

\section{The glass ceiling has a crack}

The majority of the respondents indicated that progress had been made with regard to the number of women in higher education administration positions. However, most indicated the process had been slow and that the increase in numbers of women administrators did not go all the way to the top.

Gwen indicated that she believed the glass ceiling is slowly being broken as she was seeing more and more women university administrators. Even though Gwen affirmed the breaking of the ceiling, she also noted that, "women are still more traditionally [in] academic affairs, rather than business, finance, and things like that."

Omega University is in a geographic region that Olive described as "very definitely macho-oriented." But interestingly enough there were female presidents at two of the universities within the system. One of the woman had held the president's position since 1981. Olive stated, "She's probably the first female that I really, really respected. If you had to choose someone to represent your institution, she would be the one that I would choose." Olive further noted, "I think they definitely have shown us where women can go in higher education.”

\section{CONCLUSION}

The Right Place Comes With a Price theme was based on four categories: the Price Women Pay, Gender Considerations, The Right Place Requires a Balancing Act, and the Road Block to the Right Place Has a Crack. Each of the participants shared experiences of personal sacrifice, gender considerations, and the need to balance their responsibilities. Even though these women had obtained positions in higher education administration, they paid a price. They indicated it takes personal sacrifice to be a valued employee and to be an efficient wife and mother.

The participants shared their experiences of being treated differently due to their gender. Whether it was an academic advisor, a chemistry professor, or science department colleagues, these women were challenged to demonstrate their abilities as a female. They quickly became aware of the need to realize it was okay to be a woman. Challenges existed when attempting to separate the personal from the professional issues.

To be successful as a wife, mother, and higher education administrator, it was imperative these women acquired the skill for balancing their responsibilities. Each of the participants shared the strategies they employed to successfully maintain the balancing act. However, they also noted a need for a support system. Friends, husbands, and other family members comprised their support systems. Having "three balls in the air at all times" accurately described the feelings of 


\section{RESEARCH AND REPORTS}

these women as they attempted to balance their career goals with their marital and family commitments.

These women higher education administrators were still debating the glass ceiling theory. One participant indicated the glass ceiling had turned to Teflon. She believed the rules were still different for women. Although the majority of the participants indicated progress had been made with regard to the number of women in higher education administration positions, they were not satisfied with the rate of progress or the levels at which the progress occurred.

Authors' note: Readers may access the entire dissertation entitled, "Career Paths of Women Clinical Laboratory Scientists Who Have Become Higher Education Administrators" at http://digitalcommons. unl. edu/cehsedaddiss/1.

Acknowledgements: The authors would like to thank the women participants of this case study for sharing the experiences of their career paths as they transitioned from being clinical laboratory scientists to becoming higher education administrators.

\section{REFERENCES}

1. Campbell S, LaCost B. CLS to higher education administrator: the right place - right time. Clinical Laboratory Science 2009;22(3):185-92.

2. Campbell S, LaCost B. CLS to higher education administrator: the right navigational skills. Clinical Laboratory Science 2010;23(1):12-20.

3. Ernst R. Women in higher education leadership positions: it doesn't happen by accident. Journal of College and University Personnel Association 1982;33:19-22.

4. McDonald K. Women in higher education: a new renaissance. The College Board Review 1979;111:10-13,21.
5. McCarthy M, Kuh G. A new breed of educational leadership faculty members. Journal of School Leadership 1998;8:360-72.

6. Berryman-Fink C, Lemaster B, Nelson K. The women's leadership program: a case study. Liberal Education 2003;89(1):59-64.

7. Weber M. Why women are underrepresented in educational administration. Educational Leadership: Journal of Department of Supervision and Curriculum Development, N.E.A. 1981;38:320-2.

8. Sampson S, Moore L. Is there a glass ceiling for women in development? Nonprofit Management and Leadership 2008;18(3):321-39.

9. Brooks D, Brooks L. Seven secrets of successful women. New York: McGraw-Hill; 1997.

10. Moore K. Women's access and opportunity in higher education: toward the $21^{\text {st }}$ century. Comparative Education 1987;23:23-34.

11. Shavlik D, Touchton J. The new agenda for women revisited. American Council on Education 1992;73:47-55.

12. Ballentine A. In her own words: what led pioneers to seek a community college presidency? Women in Higher Education 2001.

13. Gale S. Gender and leadership: the implications of small group research. The National Association of Women Deans, Administrators, and Counselors 1988;51:19-28.

14. Pankake A. How to overcome barriers to women in leadership. Women in Higher Education 2005;14(11):40-1.

15. Branch-Brioso K. Keeping pace, but not catching up. Diverse: Issues in Higher Education 2009;26(2):16.

16. Martin L. A report on the glass ceiling initiative. United States Department of Labor; 1991.

17. The glass ceiling initiative: are there cracks in the ceiling? United States Department of Labor; 1997.

18. Yin R. Case study research: design and methods. Thousand Oaks, CA: SAGE Publications, Inc; 2003.

19. Creswell J. Qualitative inquiry and research design: choosing among the five traditions. Thousand Oaks, CA: SAGE Publications, Inc; 1998.

20. Creswell J. Research design: qualitative, quantitative, and mixed methods approaches. Thousand Oaks, CA: SAGE Publications, Inc; 2003. 